\title{
Biological functions of natural antisense transcripts
}

\author{
Wojciech Rosikiewicz ${ }^{\bowtie}$ and Izabela Makałowska \\ Department of Bioinformatics, Institute of Molecular Biology and Biotechnology, Faculty of Biology, Adam Mickiewicz University in Poznań, \\ Poznań, Poland
}

\begin{abstract}
Natural antisense transcripts (NATs) are RNA molecules that originate from opposite DNA strands of the same genomic locus (cis-NAT) or unlinked genomic loci (trans-NAT). NATs may play various regulatory functions at the transcriptional level via transcriptional interference. NATs may also regulate gene expression levels post-transcriptionally via induction of epigenetic changes or double-stranded RNA formation, which may lead to endogenous RNA interference, RNA editing or RNA masking. The true biological significance of the natural antisense transcripts remains controversial despite many years of research. Here, we summarize the current state of knowledge and discuss the sense-antisense overlap regulatory mechanisms and their potential.
\end{abstract}

Key words: Natural antisense transcripts, antisense transcription, expression level regulation

Received: 03 June, 2016; revised: 24 June, 2016; accepted: 25 June, 2016; available on-line: 21 October, 2016

\section{INTRODUCTION}

Natural antisense transcripts (NATs) are separated into two main categories, cis or trans, depending on their genomic origin. The most popular definition of cis-NATs describes these molecules as RNA sequences

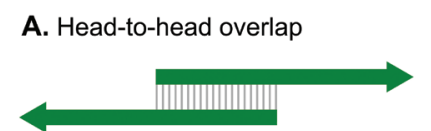

C. Embedded overlap

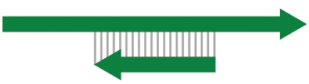

B. Tail-to-tail overlap

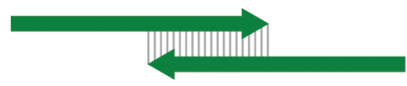

D. Overlap in trans

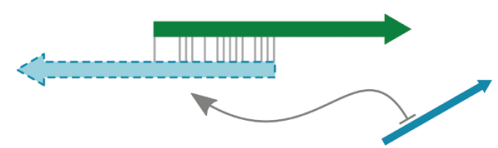

Figure 1. Types of natural antisense transcript overlap.

(A) Head-to-head overlap in cis; (B) Tail-to-tail overlap in cis; (C) Embedded overlap in cis; (D) Overlap in trans, green and blue arrows represent transcripts originated from different genomic loci, and forming double-stranded RNA. Full or partial complementarity between transcripts is indicated by a regularly spaced or disrupted "ladder" of grey vertical lines within the overlap region of cis and trans overlapping transcripts, respectively.

that originate from the opposite DNA strand of the same genomic locus, such that they physically share some genetic sequence. The overlap may be complete (Fig. 1C) or partial (Fig. 1A, B), and it may also be described as head-to-head (Fig. 1A), tail-to-tail (Fig. 1B) or embedded (Fig. 1C) (Makalowska et al., 2005). The sequences of cis-NATs within the overlap region are perfectly com- plementary between the sense and antisense RNAs, unlike trans-NATs, where transcripts originate from different genomic loci (Fig. 1D) (Vanhée-Brossollet \& Vaquero, 1998).

Almost half of the century has passed since the first natural antisense RNAs were found within the b2 region of coliphage $\lambda$ (Bovre \& Szybalski, 1969). Bovre and Szybalski concluded that double-stranded RNA (dsRNA) may be produced from overlapping transcripts under some conditions. They also suggested that RNA polymerases transcribing opposite strands in the b2 region may collide with each other, which would lead to premature transcription termination (Bovre \& Szybalski 1969). Today this is known as polymerase collision, one of the transcriptional interference scenarios (Shearwin et al., 2005). The golden age of natural antisense transcripts was far ahead despite this early discovery. Only 11 pairs of protein-coding genes with non-protein coding natural antisense counterparts were described until the late 1980 s, all in viral genomes (Inouye, 1988). These studies consolidated the hypotheses that this type of genomic architecture was rather rare and probably limited to bacterial and viral genomes (Barrell et al., 1976; Sanger et al., 1977; Szekely, 1977). However, the first discoveries of overlapping genes in eukaryotic genomes were published in 1986. Henikoff and co-workers found that the pupal cuticle protein $(P c p)$ gene of Drosophila melanogaster was embedded on the opposite DNA strand of the Gart gene within its first intron (Henikoff et al., 1986). Further discoveries in fruit fly (Spencer et al., 1986) and mouse (Williams \& Fried, 1986) were identified in the same year. The first overlapping pairs were found in humans and yeast three years later (van Duin et al., 1989).

Comprehensive discoveries of natural antisense transcripts began to emerge at the beginning of the 21 st century in various species, including plants (Mol et al., 1990; Quesada et al., 1999; Osato et al., 2003; Wang et al., 2006), fungi (Steigele \& Nieselt, 2005, David et al., 2006), vertebrates (Lehrer et al., 2002; Shendure \& Church, 2002; Zhou \& Blumberg, 2003, Veeramachaneni et al., 2005; Ge et al., 2008) and invertebrates (Misener \& Walker, 2000; Lee et al., 2005). Antisense tran- e-mail: forest@amu.edu.p

Abbreviations: NAT, natural antisense transcript; cis-NAT, natural antisense transcripts originating from the opposite DNA strands of the same genomic locus; trans-NAT, natural antisense transcripts originating from different genomic loci; dsRNA, double-stranded RNA; TI, transcriptional interference; RNAPII, RNA polymerase II; RNAi, RNA interference 
scription is now considered a widespread phenomenon that concerns up to $30 \%$ of human and mouse genomes (Yelin et al., 2003; Chen et al., 2004; Katayama et al., 2005; Zhang et al., 2006).

Natural antisense transcripts were studied using various approaches, including in silico analyses of the expressed sequence tags (Shendure \& Church, 2002, Chen et al., 2004), large-scale sequencing of full-length complementary DNAs (Osato et al., 2003; Wang et al., 2005), and tiling arrays (Li et al., 2006; Matsui et al., 2008). Current approaches are often based on next-generation sequencing technologies, such as RNA sequencing (RNASeq), single-strand RNA sequencing (ssRNA-Seq) or chromatin immunoprecipitation-sequencing (ChIP-Seq), which allowed for the discoveries of natural antisense transcripts across species on a large scale (Lu et al., 2012; Conley \& Jordan, 2012; Li et al., 2013; Luo et al., 2013).

\section{BIOLOGICAL FUNCTIONS OF NATURAL ANTISENSE TRANSCRIPTS}

The biological significance of natural antisense transcripts remains controversial despite many years of research. Some groups describe natural antisense transcripts as transcriptional noise with the potential to acquire a secondary function. Other groups posit that this latent regulatory potential is underestimated and should be considered as another level of gene expression regulation. The overlap between natural sense and antisense transcripts may regulate expression at the transcriptional level (via transcriptional interference) and/or post-transcriptional level. Regulation may be achieved via modulation of chromatin changes by NATs or the formation
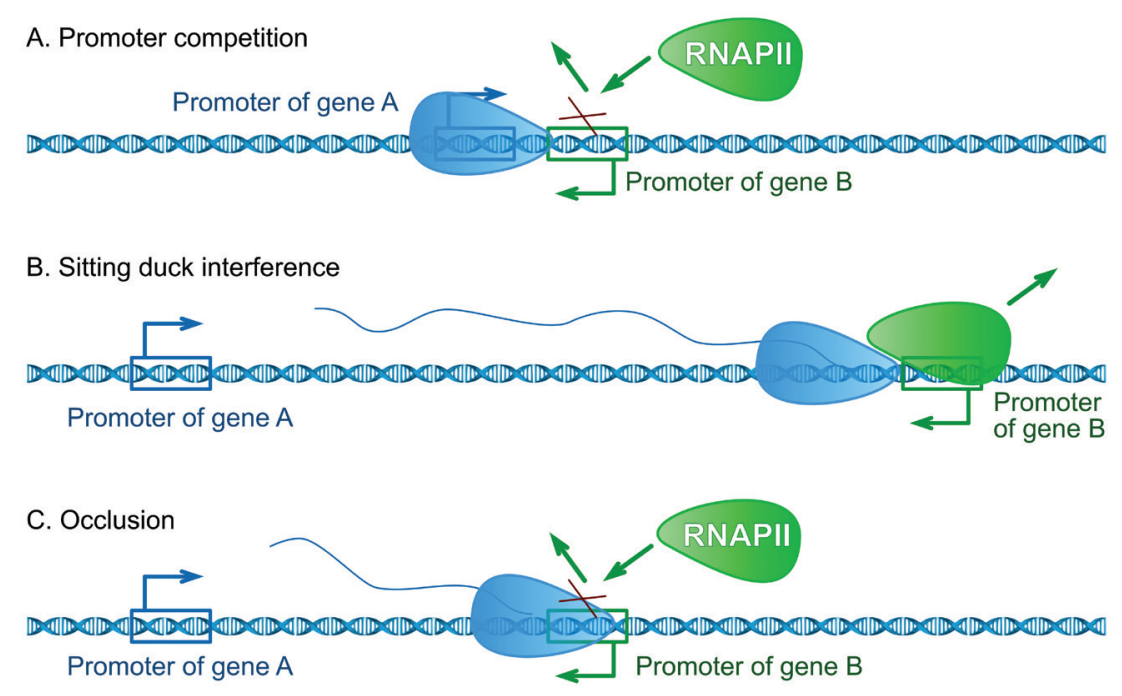

D. Polymerases collision

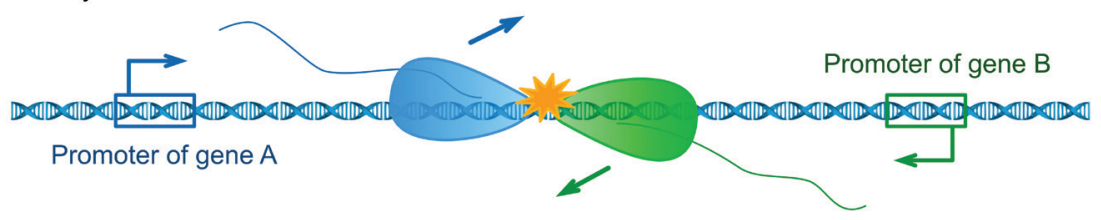

Figure 2. Mechanisms of transcriptional interference.

(A) Promoter competition; (B) Sitting duck interference; (C) Occlusion; (D) Polymerase collision; RNAPII - RNA polymerase II; Blue/green boxes with arrows indicate the transcription direction and promoter regions of genes A and B, respectively. Arrows next to RNAPIls indicate the premature end of transcription of a particular RNAPII. Based on Shearwin et al., 2005. of double-stranded RNA, which leads to RNA masking, RNA interference or RNA editing (Faghihi and Wahlestedt 2009, Lu et al., 2012, Celton et al., 2014). Expression level regulation in cis, described in sections 1 and 2, may occur at the transcriptional and post-transcriptional levmay act only post-transcriptionally (Vanhée-Brossollet \&

\section{TRANSCRIPTIONAL LEVEL OF REGULATION}

\section{Transcriptional interference}

Natural antisense transcripts may regulate expression at the level of transcription via transcriptional interference (TI). This term describes a down-regulatory influence of the two ongoing transcription processes in a relatively close proximity (Shearwin et al., 2005). TI may result in transcriptional downturn, transcriptional inhibition or early transcription termination. Four main mechanisms of transcriptional interference were proposed. The first mechanism, promoter competition, is a mechanism in which promoter regions overlap, and transcription may start only at one of them at a time interference", and it describes a situation in which RNA polymerase II (RNAPII) progresses too slowly to the enase, and it is dislodged by another RNA polymerase II (Fig. 2B). The third scenario, occlusion, olves the temporary blocking of transcription initiation at a particular promoter region by the ongoing elongation of RNAPII originating from a different promoter (Fig. 2C). The last mechanism, polymerase collision, occurs when two RNAPIIs, which are transcribing genes in opposite directions, block each other's passage and collide in a headto-head manner (Fig. 2D). Shearwin et al., thoroughly discussed these mechanisms in a review (Shearwin et al., 2005).

Transcriptional interference was intensively studied in recent years. A transcriptional collision model was inferred from human and mouse genomes analyses, which observed lower expression levels of sense-antisense transcripts in longer overlapping regions (Shearwin et al., 2005; Osato et al., 2007). RNAPII collisions were described in yeast in in vitro and in vivo models. RNAPIIs were temporary suspended during transcriptional collision events, but the elongation complexes were stable, which extended the half-life of the RNAPII involved in this process (Hobson et al., 2012). Notably, the RNAPII collision was also linked with the "off-targeting" of the activation-induced cytidine deaminase (AID), which initiates somatic hypermutations (SHM) and 
immunoglobulin (Ig) heavy chain class switch recombination (CSR) in B cells (Muramatsu et al., 2000; Meng et al., 2014; Pefanis et al., 2014). AID initiated on non$\mathrm{Ig}$ targets is related to human B cell lymphomas (Alt et al., 2013). TI was also linked with Huntington's disease, in which CAG repeat expansion within the first exon of the buntingtin (HTT) gene is associated with the disease pathology (DiFiglia et al., 1997; Chung et al., 2011). HTT expression level is down-regulated by the buntingtin antisense transcript HTTAS via transcriptional interference and/or a Dicer-dependent mechanism. Growing CAG repeat expansion in buntingtin weakens the $H T$ $T A S$ promoter strength and antisense expression level, which results in the up-regulation of HTT in Huntington's disease patients (Chung et al., 2011). TI regulates the expression level of the frequency (frq) gene in Neurospora crassa, which is a central component of the circadian clock (Xue et al., 2014; Cha et al., 2015). The expression of the antisense non-protein coding gene qrf leads to the premature transcription termination of the frq gene via transcriptional interference and mediation of chromatin modifications (Xue et al., 2014). The core circadian clock of animals is regulated in a similar manner (Koike et al., 2012; Menet et al., 2012; Vollmers et al., 2012).

How often a transcriptional interference truly controls the expression level of genes is debatable (Hobson et al., 2012). This mechanism may control the vast majority of genes because recent studies discovered that antisense non-coding RNAs are counterparts of a substantial number of genes in animals (Lehner et al., 2002; Yelin et al., 2003; Chen et al., 2004; Lapidot \& Pilpel, 2006; Conley et al., 2008) and plants (Yamada et al., 2003; Stolc et al., 2005; Li et al., 2006; Matsui et al., 2008; Lu et al., 2012; Luo et al., 2013). Models of transcriptional interference mostly suggest a negative correlation of antisense RNA expression levels (Shearwin et al., 2005). However, studies indicate that overlapping transcripts generally do not exhibit expression level correlations, and these correlations tend to be positive rather than negative (Oeder et al., 2007; Grigoriadis et al., 2009; Conley \& Jordan, 2012; Ling et al., 2013). Transcriptional interference may not generally regulate the expression level of all genes, but in some cases, TI may subtly regulate the expression levels of at least some genes where regulatory functions have emerged (Brophy \& Voigt, 2016).

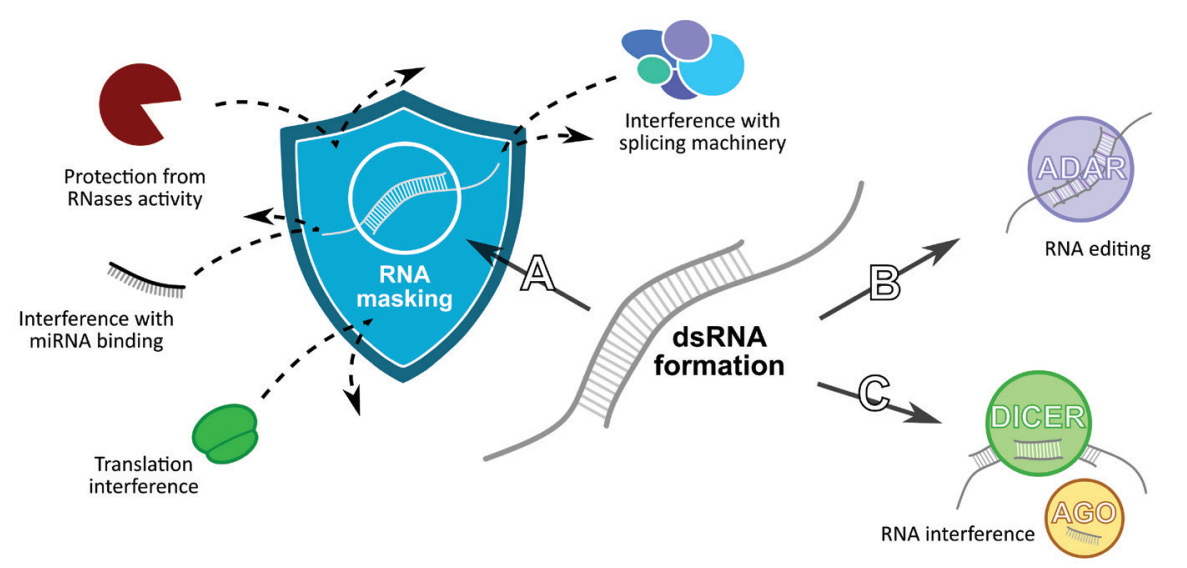

Figure 3. Regulatory roles of double-stranded RNA (dsRNA) formation.

It may lead to: (A) RNA masking, that may cause the transcript's protection from an RNase activity, interference with translation and splicing machinery, or interference with miRNA binding sites' accessibility; (B) dsRNA editing by the adenosine deaminase acting on RNA (ADAR); (C) RNA interference by Dicer-dependent post-processing of dsRNA to short siRNA, followed by Argonaute (AGO) loading into the RNA-induced silencing complex.

\section{POST-TRANSCRIPTIONAL LEVEL OF REGULATION}

\section{RNA masking}

Simultaneous transcription of antisense RNAs may lead to the formation of double-stranded RNA, which may interfere with the accessibility of the target sequences of various miRNAs (Fig. 3A). This mechanism was discovered recently for the Sirt1 gene, which possesses a target sequence for miR-34a. The miRNA target sequence is located within the overlap region between the Sirt1 gene and its antisense, Sirt1-AS. This positioning results in competition between Sirt1-AS and miR-34a for Sirt1 transcript binding (Wang et al., 2016). Overexpression of the Sirt1-AS stabilized Sirt1 mRNA and increased its half-life from 2 to 10 hours (Wang et al., 2016). Similarly, beta-secretase-1 (BACE1) expression level is negatively controlled by miR-485-5p binding and positively controlled by the formation of dsRNA by $B A C E 1$ sense and antisense (BACE1-AS) transcripts. Knockdown of $B A C E 1-A S$ exhibits the same effect as silencing of BACE1 (Modarresi et al., 2011). The imbalance of $B A C E 1, B A C E 1-A S$ and $m i R-485-5 p$ expression leads to an up-regulation of $B A C E 1$, which was linked to pathological states in patients with Alzheimer's disease (Faghihi et al., 2008; Faghihi et al., 2010). NATs are also involved in Parkinson's disease, where the short splice variant of PTEN-induced putative kinase 1 (PINK1), called svPINK1, may form a dsRNA with its antisense that is complementary at almost full-length with the sense RNA. dsRNA formation leads to stabilization of the sense transcript, and the antisense knockout resulted in the loss of the svPINK1 splice variant (Scheele et al., 2007).

Formation of dsRNA may also increase stability of the involved RNA molecules via protection from digestion by ribonucleases aimed at single-stranded RNA degradation, which was demonstrated in cyanobacterium Prochlorococcus sp. RNase E (Stazic et al., 2011). Sense-antisense duplexes may protect RNA molecules from entering into nonsense-mediated decay (NMD), which was demonstrated in yeasts (Wery et al., 2016). Protection against single-stranded RNases was also demonstrated in $n d s-2 a$, which is a stable, naturally occurring human
dsRNA of sense-antisense transcription origin. Knockdown of $n d s-2 a$ dsRNA using strand-specific locked nucleic acid (LNA) gapmers resulted in numerous mitotic-related effects which suggests a functional role of these RNA duplexes (Portal et al., 2015).

dsRNA formation may influence alternative splicing of the rat and human $\alpha$-thyroid hormone receptor (TR $a$ ) gene, which encodes two splice variants, TRa1 (active, hormone-binding variant) and TRa2 (inactive, non-hormone-binding variant). NAT only binds to the longer, non-hormone-binding TRa2 splice variant. TRa2-NAT dsRNA formation is presumably responsible for the negative regulation of $\mathrm{TR} a 2$ expression level, which pre- 
vents the inactive variant expression (Munroe \& Lazar, 1991; Hastings et al., 2000). Munroe recently demonstrated that the TRa2 variant was not present in marsupials and platypus, and comparative analysis revealed that only $T R a 2$ was adopted as a TR $a$ expression level regulator in eutherian lineage (Munroe et al., 2015).

Another example involves regulation of the E-cadherin - protein complex which plays a key role in cellular adhesion. Dysfunctions of this complex are associated with increased tumor metastasis (Beavon, 2000). Zeb2 is a transcriptional repressor of E-cadherin. Expression of the Zeb2 NAT induces an alternative splicing of Zeb2, which results in the presence of an intron containing an internal ribosome entry site (IRES) that is necessary for the Zeb2 protein synthesis (Beltran et al., 2008).

RNA masking may also inhibit expression at the translational level, which was demonstrated in the $B C M A$ gene. The amount of BCMA mRNA in cells is not altered by the expression level of antisense (normal or increased expression). However, increased expression of $B C M A$-antisense RNA results in a lower amount of the BCMA protein (Hatzoglou et al., 2002). The functional significance of NATs at the translational level was demonstrated in more detail for PU.1 transcription factor expression regulation, where the PU.1 antisense interferes with the formation of the PU.1 elongating complex (eEF1A-mRNA) (Ebralidze et al., 2008).

\section{RNA editing (A-to-I)}

Natural antisense transcripts that form double-stranded RNA could become a target for the adenosine deaminase acting on RNA (ADAR) in a process called RNA editing (Fig. 3B). ADAR editing leads to adenosine (A) deamination into inosine $(\mathrm{I})$, which is further interpreted as guanosine $(G)$ by the cellular translational and splicing machinery (Nigita et al., 2015). Peters and co-workers investigated the 162-nt long overlap region of the 4 -rmp and sas-10 overlapping gene sequences in Drosophila menalogaster and discovered that approximately $20 \%$ of the $4 f-r n p$ and sas-10 transcripts show marks of RNA editing at random positions (Peters et al., 2003). The extent to which RNA editing plays a biologically significant role in natural antisense transcripts is not fully understood (Wight and Werner 2013). Nevertheless, reports of thousands of human, mouse and fly RNA editing sites are reported in different contexts (Laganà et al., 2012; Wang et al., 2013; Ramaswami \& Li, 2014; Zhang et al., 2016). Therefore, the discovery of the links of these sites with NATs on a broader scale is likely a matter of time.

\section{RNA interference}

Another possibility for the functional relevance of natural antisense transcripts is post-transcriptional

dsRNA-dependent RNA interference (RNAi) through endo-siRNA - endogenous small-interfering RNAs (Fig. 3C). Endo-siRNAs were reported in various species, including plants (Borsani et al., 2005; Zhang et al., 2012; Li et al., 2013; Yu et al., 2016), fungi (Lee et al., 2010) and animals (Tam et al., 2008; Watanabe et al., 2008; Okamura et al., 2011; Werner et al., 2014; Ling et al., 2016). The mechanism of endo-siRNA maturation from NATderived dsRNA that is understood the most, suggests a Dicer-dependent character of dsRNA processing to short siRNA, followed by Argonaute loading into the molecular silencing machinery, RNA-induced silencing complex (RISC) (Czech \& Hannon, 2011; Kwak \& Tomari, 2012). However, studies of Neurospora crassa suggest that siRNA is formed using an unknown Dicer-un- related pathway, forming the so-called dicer-independent small interfering RNA (disiRNA) (Lee et al., 2010). Natural antisense transcripts were also described as a source of short RNA (Sox4_sir3) in mouse, which resembled piRNA rather than siRNA. Sox4_sir3 is 24-nt long and possesses a 5'-end-sequence bias for uridine. Comparative in silico analyses suggest that Sox4_sir3 is a central nervous system-related piRNA (Ling et al., 2016).

Formation of dsRNA may protect natural antisense transcripts from single-stranded RNase activity and simultaneously limit the prevalence of NATs primarily to the nucleus. Formation or transport of a double-stranded RNA to the cytoplasm could trigger an immune response. Cellular machinery recognizes dsRNA as a viral infection and promotes the inhibition of protein synthesis and the transcriptional induction of interferon and other cytokines, which may ultimately lead to cell death (Wang \& Carmichael, 2004; Kumar et al., 2004; Gantier \& Williams, 2007). NAT-related dsRNAs are primarily located in the nucleus, possibly to avoid the abovementioned immune response (Faghihi \& Wahlestedt, 2006; van Heesch et al., 2014; Portal et al., 2015). The regulatory function of NATs in the cytoplasm is limited to regulation by endo-siRNAs, which are present in the nucleus and cytoplasm (Portal et al., 2015). However, stable sense-antisense duplexes that were predominantly located in the cytoplasm were also reported (Dallosso et al., 2007; Michael et al., 2011). Therefore, the extent to which the cellular interferon pathway is activated in response to naturally occurring dsRNAs is debatable (Wang \& Carmichael, 2004).

Genome-wide analyses using RNA-Seq and singlestranded RNA-Seq protocols, strengthened by parallel analyses of small RNA or degradome sequencing, were proposed in recent years to expand our knowledge of the NATs involved in the endogenous RNA interference ( $\mathrm{Lu}$ et al., 2012; Li et al., 2013; Werner et al., 2014; Yu et al., 2016). These studies revealed that nearly $4 \%$ of the Arabidopsis thaliana cis-NATs produce putative endo-siRNAs, and approximately 200 of these endo-siRNAs exhibit relatively high expression levels $\geq 10$ RPKM (Reads Per Kilobase per Million mapped reads) (Li et al., 2013). Studies in orchid (Dendrobium officinale) identified 63 natural antisense transcripts that produced endo-siRNAs (Yu et al., 2016). A total of 2292 NATs were reported as a source of endo-siRNA in rice (Oryza sativa) (Lu et al., 2012). A large-scale analysis of the small RNA transcriptome in human embryonic kidney cells revealed that the senseantisense transcription of 169 RefSeq genes may lead to the formation of endo-siRNAs. These endo-siRNAs were also mostly enriched by AGO1 and RNAPII, which correlated with the actively transcribed endo-siRNA precursors (Werner et al., 2014). Our understanding of the biological impact of these findings requires further study, but the use of next-generation sequencing for large-scale endo-siRNA studies has already revealed their widespread occurrence and regulatory potential.

\section{Epigenetic modifications}

Natural antisense transcripts may regulate expression levels of the sense genes and mediate chromatin modifications within the gene sequence, promoter or enhancer regions, the entire locus or even surrounding genomic loci (Li \& Ramchandran, 2010; Halley et al., 2013; Wight \& Werner, 2013). For example, expression of the HBA2 gene may be down-regulated by a repressive chromatin modification within the $H B A 2$ promoter regions by its 
antisense transcript, LUC7 (Tufarelli et al., 2003). Another example is brain-derived neurotrophic factor (BDNF) and its antisense, $B D N F-A S$, which may play a role in the guidance, introduction and maintenance of the histone $\mathrm{H} 3 \mathrm{~K} 27 \mathrm{me} 3$ modification within the BDNF locus (Modarresi et al., 2012b). BDNF-AS was associated with the recruitment of polycomb repressive complex 2 (PCR2), which locally induces the trimethylation of histone H3K27 within the locus, without exerting any effect on the surrounding loci (Modarresi et al., 2012b). Decreased expression of BDNF is associated with Alzheimer's, Parkinson's, and Huntington's diseases (Bathina \& Das, 2015). Knockout of $B D N F-A S$ results in an up-regulation of $B D N F$ expression levels, which supports the therapeutic potential of this mechanism (Modarresi et al., 2012a). In contrast to $B D N F-A S$, which locally induces histone modifications, an antisense of the mouse Konq1 gene, Konq1ot1, may impact the entire Konq1 domain. Konq1ot1 is responsible for the recruitment of PCR2 and G9 a methylotransferases and the induction of repressive histone modifications of the Kcnq1 gene and several upand down-stream localized genes (Pandey et al., 2008). Notably, large-scale interactions of Konq1ot1 were present in a linage-specific manner in mouse placenta, but not fetal liver. The regulatory significance of Konq1ot1 is emphasized by the insertion of a premature transcriptional stop signal and synthesis of a truncated Konq1ot1 transcript, which results in an up-regulation of all genes in the Konq1 domain (Mancini-Dinardo et al., 2006). NAT recruitment of PCR2 is also involved in the X-chromosome inactivation by $X$-inactive specific transcript (Xist) and its antisense, Tsix (Halley et al., 2013). Tsix biallelic expression before the $\mathrm{X}$-inactivation leads to the silencing of Xist on both $\mathrm{X}$ chromosomes via $\mathrm{H} 3 \mathrm{~K} 27 \mathrm{me} 3$ histone modifications over the Xist promoter regions (Ohhata et al., 2015). Tsix expression becomes monoallelic at the early stage of chromosome inactivation, which results in a de-repression of the Xist promoter and heterochromatization of the chromosome $\mathrm{X}$ where Tsix was silenced (Lee et al., 1999, Ohhata et al., 2015). Tsix dysfunctions may lead to several X-linked diseases (Chaligné \& Heard, 2014; Charles Richard \& Ogawa, 2016).

\section{NAT REGULATORY FUNCTIONS IN TRANS}

Natural antisense transcripts that function in a trans arrangements (trans-NAT) have not been studied as intensively as cis-NATs. Trans-NAT sequences within the "overlap" region may not be fully complementary to the target sequence because these sequences originate from different genomic loci (Vanhée-Brossollet \& Vaquero, 1998). However, this partial complementarity may still lead to the formation of double-stranded RNAs. Recent studies demonstrated that thousands of human (Szcześniak \& Makałowska, 2016) and plant (Szcześniak et al., 2016) transcripts exhibit the potential to form lncRNA-RNA duplexes, and new functional trans-NATs are continuously being discovered (Roberts \& Morris, 2013). Every DNA-mediated duplication and retrotransposition event is generally a source of a sequence that is complementary to the original sequence. The emerged copy possesses the potential for expression, which may lead to trans-NAT formation (Muro \& Andrade-Navarro, 2010; Roberts \& Morris, 2013). One well-studied example is the nitric oxide (NO) neurotransmitter in Lymnaea stagnalis, which is involved in long-term memory formation and associated with food-reward conditioning (Kemenes et al., 2002). NO production is catalyzed by
NO-synthase (NOS), which is negatively regulated in trans by the NOS pseudogene antisense transcript (antiNOS-2) via dsRNA formation of NOS mRNA and antiNOS-2. Decreased antiNOS-2 expression levels facilitate memory formation in classical conditioning (Korneev et al., 1999; Korneev et al., 2002; Korneev et al., 2013). Pseudogenes in mouse oocytes are also a source of endo-siRNAs that originate from dsRNA that forms between parental $\mathrm{mRNA}$ and homologous pseudogene antisense sequences (Tam et al., 2008; Watanabe et al., 2008). The identified endo-siRNAs complex are Dicer-dependent and enriched with Ago2. Target sequence expression levels of the detected complex increased in Dicer and Ago2 knockout mutants (Watanabe et al., 2008).

Three potential endo-siRNA precursor regions, esiRNA1, esiRNA2 and esiRNA3 were identified in the human hepatocellular carcinoma pseudogene $\psi \mathrm{PPM} 1 \mathrm{~K}$ sequence. Endo-siRNA may arise from these precursors in two ways. The first mechanism is related with

esiRNA3 and based on dsRNA formation by $\psi \mathrm{PPM} 1 \mathrm{~K}$ antisense and the cognate gene (PPM1K) transcripts. The second mechanisms involves esiRNA1 and leads to endo-siRNA maturation from the hairpin structure formed by the $\psi P P M 1 \mathrm{~K}$ transcript. esiRNA1 may down-regulate the expression of the cognate PPM1K (protein phosphatase, $\mathrm{Mg}^{2+} / \mathrm{Mn}^{2+}$-dependent) gene and NEK8 (NIMA-related kinase 8) gene. These effects were not observed in a ४PPM1K mutant with deletion of the esiRNA1 precursor region (Chan et al., 2013).

Trans-NATs also induce chromatin epigenetic changes. Methylation of the Oct4 gene promoter region by the recruitment of E₹h2 methylotransferase is linked to an antisense transcript of Oct4-pseudogene 5 - asOct4-pg5. Separate knockdowns of Eqh2 and asOct4-pg5 resulted in Oct4 up-regulation via demethylation of its promoter regions. A down-regulatory influence of the asOct4-pg5 was also RNAi independent (Hawkins \& Morris, 2010).

Natural antisense transcripts are able to regulate the sense gene expression levels in a cis and trans manner in some genomic arrangements. For example, the DHRS4 gene cluster is composed of three highly homologous genes, DHRS4, DHRS4L1 and DHRS4L2, and the DHRS4 gene is regulated in cis by AS1DHRS4, a headto-head antisense transcript. AS1DHRS4 also regulates DHRS4L1 and DHRS4L2 genes in trans. AS1DHRS4 controls the epigenetic silencing of all promoter regions within the DHRS4 gene cluster via interaction with EZH2 and G9C methylotransferases. Knockout of AS1DHRS4 increases the expression of genes in the DHRS4 gene cluster (Li et al., 2012).

The number of known pseudogenes that gained a new regulatory function by antisense transcription is small, but yearly discoveries refine our understanding of the potential of trans-NATs to regulate gene expression on another level.

\section{CONCLUDING REMARKS}

Natural antisense transcripts possess a great potential to regulate the sense gene expression at transcriptional and post-transcriptional levels, and their functional relevance is supported by the numerous reports of their tissue-specific expression (Lu et al., 2012; Conley \& Jordan, 2012; Ling et al., 2013).

Notably, a growing number of studies link NATs with various human diseases, including the Fragile $\mathrm{X}$ syndrome (Ladd et al., 2007; Khalil et al., 2008), Alzheimer's (Parenti et al., 2007; Faghihi et al., 2008; Faghihi 
et al., 2010; Bathina \& Das, 2015), Parkinson's (Scheele et al., 2007; Bathina \& Das, 2015), and Huntington's diseases (Chung et al., 2011; Bathina \& Das, 2015), and cancer (Dallosso et al., 2007; Yu et al., 2008; Pasmant et al., 2011; Chaligné \& Heard, 2014). NATs also play a role in hypertension, asthma or thyroid dysfunction (Michael et al., 2011), and metabolic (Li et al., 2012), immune (Hatzoglou et al., 2002) or cardiovascular disorders (Annilo et al., 2009). The medical applications of the regulatory functions exerted by NATs over their sense gene counterparts were scrutinized in comprehensive reviews by Khorkova (Khorkova et al., 2014) and Halley (Halley et al., 2013).

The biological significance of natural antisense transcripts will likely be debatable for a long time. However, our increasing understanding of the NAT biology sheds new light on the functional importance of antisense transcription, which may not regulate every single natural sense-antisense pair, but is surely essential for the proper functioning of all living organisms.

\section{Acknowledgements:}

This work was supported by the National Science Centre (grant No. 2013/11/N/NZ2/02524 to W.R) and the KNOW Poznan RNA Centre (grant No. 01/ KNOW2/2014).

\section{REFERENCES}

Alt FW, Zhang Y, Meng FL, Guo C, Schwer B, (2013) Mechanisms of programmed DNA lesions and genomic instability in the immune system. Cell 152: 417-429. http://dx.doi.org/10.1016/j. cell.2013.01.007

Annilo T, Kepp K, Laan M, (2009) Natural antisense transcript of natriuretic peptide precursor A (NPPA): structural organization and modulation of NPPA expression. BMC Mol Biol 10: 81. http:// dx.doi.org/10.1186/1471-2199-10-81

Barrell BG, Air GM, Hutchison CA 3rd, (1976) Overlapping genes in bacteriophage phiX174. Nature 264: $34-41$

Bathina S, Das UN, (2015) Brain-derived neurotrophic factor and its clinical implications. Arch Med Sci 11: 1164-1178. http://dx.doi. org/10.5114/aoms.2015.56342

Beavon IR, (2000) The E-cadherin-catenin complex in tumour metastasis: structure, function and regulation. Eur J Cancer 36: 1607-1620

Beltran M, Puig I, Pena C, Garcia JM, Alvarez AB, Pena R, Bonilla F, de Herreros AG, (2008) A natural antisense transcript regulates Zeb2/Sip1 gene expression during Snail1-induced epithelialmesenchymal transition. Genes Dev 22: 756-769. http://dx.doi. org/10.1101/gad.455708

Borsani O, Zhu J, Verslues PE, Sunkar R, Zhu JK, (2005) Endogenous siRNAs derived from a pair of natural cis-antisense transcripts regulate salt tolerance in Arabidopsis. Cell 123: 1279-1291. http:// dx.doi.org/10.1016/j.cell.2005.11.035

Bovre K, Szybalski W, (1969) Patterns of convergent and overlapping transcription within the b2 region of coliphage lambda. Virology 38: 614-626

Brophy JA, Voigt CA, (2016) Antisense transcription as a tool to tune gene expression. Mol Syst Biol 12: 854. http://dx.doi.org/10.15252/ msb.20156540

Celton JM, Gaillard S, Bruneau M, Pelletier S, Aubourg S, Martin-Magniette ML, Navarro L, Laurens F, Renou JP, (2014) Widespread anti-sense transcription in apple is correlated with siRNA production and indicates a large potential for transcriptional and/or post-transcriptional control. New Phytol 203: 287-299. http://dx.doi. org/10.1111/nph.12787

Cha J, Zhou M, Liu Y, (2015) Mechanism of the Neurospora circadian clock, a FREQUENCY-centric view. Biochemistry 54: 150-156. http://dx.doi.org/10.1021/bi5005624

Chaligne R, Heard E, (2014) X-chromosome inactivation in development and cancer. FEBS Lett 588: 2514-2522. http://dx.doi. org/10.1016/j.febslet.2014.06.023

Chan WL, Yuo CY, Yang WK, Hung SY, Chang YS, Chiu CC, Yeh KT, Huang HD, Chang JG, (2013) Transcribed pseudogene psiPPM1K generates endogenous siRNA to suppress oncogenic cell growth in hepatocellular carcinoma. Nucleic Acids Res 41: 3734-3747. http://dx.doi.org/10.1093/nar/gkt047

Charles Richard JL, Ogawa Y, (2016) Understanding the complex circuitry of lncRNAs at the $\mathrm{X}$-inactivation center and its implications in disease conditions. Curr Top Microbiol Immunol 394: 1-27. http:// dx.doi.org/10.1007/82_2015_443

Chen J, Sun M, Kent WJ, Huang X, Xie H, Wang W, Zhou G, Shi RZ, Rowley JD, (2004) Over 20\% of human transcripts might form sense-antisense pairs. Nucleic Acids Res 32: 4812-4820. http://dx.doi. org/10.1093/nar/gkh818

Chung DW, Rudnicki DD, Yu L, Margolis RL, (2011) A natural antisense transcript at the Huntington's disease repeat locus regulates HTT expression. Hum Mol Genet 20: 3467-3477. http://dx.doi. org $/ 10.1093 / \mathrm{hmg} / \mathrm{ddr} 263$

Conley AB, Jordan IK, (2012) Epigenetic regulation of human cis-natural antisense transcripts. Nucleic Acids Res 40: 1438-1445. http:// dx.doi.org/10.1093/nar/gkr1010

Conley AB, Miller WJ, Jordan IK, (2008) Human cis natural antisense transcripts initiated by transposable elements. Trends Genet 24: 5356. http://dx.doi.org/10.1016/j.tig.2007.11.008

Czech B, Hannon GJ, (2011) Small RNA sorting: matchmaking for Argonautes. Nat Rev Genet 12: 19-31. http://dx.doi.org/10.1038/ nrg2916

Dallosso AR, Hancock AL, Malik S, Salpekar A, King-Underwood L, Pritchard-Jones K, Peters J, Moorwood K, Ward A, Malik KT, Brown KW, (2007) Alternately spliced WT1 antisense transcripts interact with WT1 sense RNA and show epigenetic and splicing defects in cancer. RNA 13: 2287-2299. http://dx.doi.org/10.1261/ rna.562907

David L, Huber W, Granovskaia M, Toedling J, Palm CJ, Bofkin L, Jones T, Davis RW, Steinmetz LM, (2006) A high-resolution map of transcription in the yeast genome. Proc Natl Acad Sci US A 103: 5320-5325. http://dx.doi.org/10.1073/pnas.0601091103

DiFiglia M, Sapp E, Chase KO, Davies SW, Bates GP, Vonsattel JP, Aronin N, (1997) Aggregation of huntingtin in neuronal intranuclear inclusions and dystrophic neurites in brain. Science 277: 1990-1993

Ebralidze AK, Guibal FC, Steidl U, Zhang P, Lee S, Bartholdy B, Jorda MA, Petkova V, Rosenbauer F, Huang G, Dayaram T, Klupp J, O’Brien KB, Will B, Hoogenkamp M, Borden KL, Bonifer C, Tenen DG, (2008) PU.1 expression is modulated by the balance of functional sense and antisense RNAs regulated by a shared cis-regulatory element. Genes Dev 22: 2085-2092. http://dx.doi. org/10.1101/gad.1654808

Faghihi MA, Modarresi F, Khalil AM, Wood DE, Sahagan BG, Morgan TE, Finch CE, St Laurent G 3rd, Kenny PJ, Wahlestedt C, (2008) Expression of a noncoding RNA is elevated in Alzheimer's disease and drives rapid feed-forward regulation of beta-secretase. Nat Med 14: 723-730. http://dx.doi.org/10.1038/nm1784

Faghihi MA, Wahlestedt C, (2006) RNA interference is not involved in natural antisense mediated regulation of gene expression in mammals. Genome Biol 7: R38. http://dx.doi.org/10.1186/gb-2006-7$5-\mathrm{r} 38$

Faghihi MA, Wahlestedt C, (2009) Regulatory roles of natural antisense transcripts. Nat Rev Mol Cell Biol 10: 637-643. http://dx.doi. org/10.1038/nrm2738

Faghihi MA, Zhang M, Huang J, Modarresi F, Van der Brug MP, Nalls MA, Cookson MR, St-Laurent G 3rd, Wahlestedt C, (2010) Evidence for natural antisense transcript-mediated inhibition of microRNA function. Genome Biol 11: R56. http://dx.doi.org/10.1186/ gb-2010-11-5-r56

Gantier MP, Williams BR, (2007) The response of mammalian cells to double-stranded RNA. Cytokine Growth Factor Rev 18: 363-371. http://dx.doi.org/10.1016/j.cytogfr.2007.06.016

Ge X, Rubinstein WS, Jung YC, Wu Q, (2008) Genome-wide analysis of antisense transcription with Affymetrix exon array. BMC Genomics 9: 27. http://dx.doi.org/10.1186/1471-2164-9-27

Grigoriadis A, Oliver GR, Tanney A, Kendrick H, Smalley MJ, Jat P, Neville AM, (2009) Identification of differentially expressed sense and antisense transcript pairs in breast epithelial tissues. BMC Genomics 10: 324. http://dx.doi.org/10.1186/1471-2164-10-324

Halley P, Khorkova O, Wahlestedt C, (2013) Natural antisense transcripts as therapeutic targets. Drug Discov Today Ther Strateg 10: e119e125. http://dx.doi.org/10.1016/j.ddstr.2013.03.001

Hastings ML, Ingle HA, Lazar MA, Munroe SH, (2000) Post-transcriptional regulation of thyroid hormone receptor expression by cis-acting sequences and a naturally occurring antisense RNA. J Biol Chem 275: 11507-11513

Hatzoglou A, Deshayes F, Madry C, Lapree G, Castanas E, Tsapis A, (2002) Natural antisense RNA inhibits the expression of BCMA, a tumour necrosis factor receptor homologue. BMC Mol Biol 3: 4

Hawkins PG, Morris KV, (2010) Transcriptional regulation of Oct4 by a long non-coding RNA antisense to Oct4-pseudogene 5. Transcription 1: 165-175. http://dx.doi.org/10.4161/trns.1.3.13332

Henikoff S, Keene MA, Fechtel K, Fristrom JW, (1986) Gene within a gene: nested Drosophila genes encode unrelated proteins on opposite DNA strands. Cell 44: 33-42

Hobson DJ, Wei W, Steinmetz LM, Svejstrup JQ, (2012) RNA polymerase II collision interrupts convergent transcription. Mol Cell 48: 365-374. http://dx.doi.org/10.1016/j.molcel.2012.08.027 
Inouye M, (1988) Antisense RNA: its functions and applications in gene regulation - a review. Gene 72: 25-34

Katayama S, Tomaru Y, Kasukawa T, Waki K, Nakanishi M, Nakamura M, Nishida H, Yap CC, Suzuki M, Kawai J, Suzuki H, Carninci P, Hayashizaki Y, Wells C, Frith M, Ravasi T, Pang KC, Hallinan J, Mattick J, Hume DA, Lipovich L, Batalov S, Engstrom PG, Mizuno Y, Faghihi MA, Sandelin A, Chalk AM, Mottagui-Tabar S, Liang Z, Lenhard B, Wahlestedt C, (2005) Antisense transcription in the mammalian transcriptome. Science 309: 1564-1566. http://dx.doi. org/10.1126/science.1112009

Kemenes I, Kemenes G, Andrew RJ, Benjamin PR, O'Shea M, (2002) Critical time-window for NO-cGMP-dependent long-term memory formation after one-trial appetitive conditioning. J Neurosci 22: 1414-1425

Khalil AM, Faghihi MA, Modarresi F, Brothers SP, Wahlestedt C, (2008) A novel RNA transcript with antiapoptotic function is silenced in fragile X syndrome. PLoS One 3: e1486. http://dx.doi. org/10.1371/journal.pone.0001486

Khorkova O, Myers AJ, Hsiao J, Wahlestedt C, (2014) Natural antisense transcripts. Hum Mol Genet 23: R54-R63. http://dx.doi. org $/ 10.1093 / \mathrm{hmg} / \mathrm{ddu} 207$

Koike N, Yoo SH, Huang HC, Kumar V, Lee C, Kim TK, Takahashi JS, (2012) Transcriptional architecture and chromatin landscape of the core circadian clock in mammals. Science 338: 349-354. http:// dx.doi.org/10.1126/science.1226339

Korneev S, O'Shea M, (2002) Evolution of nitric oxide synthase regulatory genes by DNA inversion. Mol Biol Evol 19: 1228-33

Korneev SA, Kemenes I, Bettini NL, Kemenes G, Staras K, Benjamin PR, O'Shea M, (2013) Axonal trafficking of an antisense RNA transcribed from a pseudogene is regulated by classical conditioning. Sci Rep 3: 1027. http://dx.doi.org/10.1038/srep01027

Korneev SA, Park JH, O'Shea M, (1999) Neuronal expression of neural nitric oxide synthase (nNOS) protein is suppressed by an antisense RNA transcribed from an NOS pseudogene. I Neurosci 19: 7711-7720

Kumar M, Carmichael GG, (1998) Antisense RNA: function and fate of duplex RNA in cells of higher eukaryotes. Microbiol Mol Biol Rev 62: 1415-1434

Kwak PB, Tomari Y, (2012) The N domain of Argonaute drives duplex unwinding during RISC assembly. Nat Struct Mol Biol 19: 145151. http://dx.doi.org/10.1038/nsmb.2232

Ladd PD, Smith LE, Rabaia NA, Moore JM, Georges SA, Hansen RS, Hagerman RJ, Tassone F, Tapscott SJ, Filippova GN, (2007) An antisense transcript spanning the CGG repeat region of FMR1 is upregulated in premutation carriers but silenced in full mutation individuals. Hum Mol Genet 16: 3174-3187. http://dx.doi.org/10.1093/ $\mathrm{hmg} / \mathrm{ddm} 293$

Lagana A, Paone A, Veneziano D, Cascione L, Gasparini P, Carasi S, Russo F, Nigita G, Macca V, Giugno R, Pulvirenti A, Shasha D, Ferro A, Croce CM, (2012) miR-EdiTar: a database of predicted A-to-I edited miRNA target sites. Bioinformatics 28: 3166-3168. http://dx.doi.org/10.1093/bioinformatics/bts589

Lapidot M, Pilpel Y, (2006) Genome-wide natural antisense transcription: coupling its regulation to its different regulatory mechanisms. EMBO Rep 7: 1216-1222. http://dx.doi.org/10.1038/sj.embor.7400857

Lee HC, Li L, Gu W, Xue Z, Crosthwaite SK, Pertsemlidis A, Lewis ZA, Freitag M, Selker EU, Mello CC, Liu Y, (2010) Diverse pathways generate microRNA-like RNAs and Dicer-independent smal interfering RNAs in fungi. Mol Cell 38: 803-814. http://dx.doi. org/10.1016/j.molcel.2010.04.005

Lee JT, Davidow LS, Warshawsky D, (1999) Tsix, a gene antisense to Xist at the X-inactivation centre. Nat Genet 21: 400-404. http://dx. doi.org/10.1038/7734

Lee S, Bao J, Zhou G, Shapiro J, Xu J, Shi RZ, Lu X, Clark T, Johnson D, Kim YC, Wing C, Tseng C, Sun M, Lin W, Wang J, Yang $\mathrm{H}$, Wang J, Du W, Wu CI, Zhang X, Wang SM, (2005) Detecting novel low-abundant transcripts in Drosophila. RNA 11: 939-946. http://dx.doi.org/10.1261/rna.7239605

Lehner B, Williams G, Campbell RD, Sanderson CM, (2002) Antisense transcripts in the human genome. Trends Genet 18: 63-5

Li K, Ramchandran R, (2010) Natural antisense transcript: a concomitant engagement with protein-coding transcript. Oncotarget 1: 447 452. http://dx.doi.org/10.18632/oncotarget.178

Li L, Wang X, Stolc V, Li X, Zhang D, Su N, Tongprasit W, Li S, Cheng Z, Wang J, Deng XW, (2006) Genome-wide transcription analyses in rice using tiling microarrays. Nat Genet 38: 124-129. http://dx.doi.org/10.1038/ng1704

Li Q, Su Z, Xu X, Liu G, Song X, Wang R, Sui X, Liu T, Chang X, Huang D, (2012) AS1DHRS4, a head-to-head natural antisense transcript, silences the DHRS4 gene cluster in cis and trans. Proc Natl Acad Sci U S A 109: 14110-14115. http://dx.doi.org/10.1073/ pnas.1116597109

Li S, Liberman LM, Mukherjee N, Benfey PN, Ohler U, (2013) Integrated detection of natural antisense transcripts using strand-specif- ic RNA sequencing data. Genome Res 23: 1730-1739. http://dx.doi. org/10.1101/gr.149310.112

Ling KH, Brautigan PJ, Moore S, Fraser R, Cheah PS, Raison JM, Babic M, Lee YK, Daish T, Mattiske DM, Mann JR, Adelson DL, Thomas PQ, Hahn CN, Scott HS, (2016) Derivation of an endogenous small RNA from double-stranded Sox4 sense and natural antisense transcripts in the mouse brain. Genomics 107: 88-99. http:// dx.doi.org/10.1016/j.ygeno.2016.01.006

Ling MH, Ban Y, Wen H, Wang SM, Ge SX, (2013) Conserved expression of natural antisense transcripts in mammals. BMC Genomics 14: 243. http://dx.doi.org/10.1186/1471-2164-14-243

Lu T, Zhu C, Lu G, Guo Y, Zhou Y, Zhang Z, Zhao Y, Li W, Lu Y, Tang W, Feng Q, Han B, (2012) Strand-specific RNA-seq reveals widespread occurrence of novel cis-natural antisense transcripts in rice. BMC Genomics 13: 721. http://dx.doi.org/10.1186/1471-216413-721

Luo C, Sidote DJ, Zhang Y, Kerstetter RA, Michael TP, Lam E, (2013) Integrative analysis of chromatin states in Arabidopsis identified potential regulatory mechanisms for natural antisense transcript production. Plant J 73: 77-90. http://dx.doi.org/10.1111/tpj.12017

Makalowska I, Lin CF, Makalowski W, (2005) Overlapping genes in vertebrate genomes. Comput Biol Chem 29: 1-12. http://dx.doi. org/10.1016/j.compbiolchem.2004.12.006

Mancini-Dinardo D, Steele SJ, Levorse JM, Ingram RS, Tilghman SM, (2006) Elongation of the Kcnq1ot1 transcript is required for genomic imprinting of neighboring genes. Genes Dev 20: 1268-1282. http://dx.doi.org/10.1101/gad.1416906

Matsui A, Ishida J, Morosawa T, Mochizuki Y, Kaminuma E, Endo TA, Okamoto M, Nambara E, Nakajima M, Kawashima M, Satou M, Kim JM, Kobayashi N, Toyoda T, Shinozaki K, Seki M, (2008) Arabidopsis transcriptome analysis under drought, cold, high-salinity and $\mathrm{ABA}$ treatment conditions using a tiling array. Plant Cell Physiol 49: 1135-1149. http://dx.doi.org/10.1093/pcp/pcn101

Menet JS, Rodriguez J, Abruzzi KC, Rosbash M, (2012) Nascent-Seq reveals novel features of mouse circadian transcriptional regulation. Elife 1: e00011. http://dx.doi.org/10.7554/eLife.00011

Meng FL, Du Z, Federation A, Hu J, Wang Q, Kieffer-Kwon KR, Meyers RM, Amor C, Wasserman CR, Neuberg D, Casellas R, Nussenzweig MC, Bradner JE, Liu XS, Alt FW, (2014) Convergent transcription at intragenic super-enhancers targets AID-initiated genomic instability. Cell 159: 1538-1548. http://dx.doi.org/10.1016/j. cell.2014.11.014

Michael DR, Phillips AO, Krupa A, Martin J, Redman JE, Altaher A, Neville RD, Webber J, Kim MY, Bowen T, (2011) The human hyaluronan synthase 2 (HAS2) gene and its natural antisense RNA exhibit coordinated expression in the renal proximal tubular epithelial cell. J Biol Chem 286: 19523-19532. http://dx.doi.org/10.1074/jbc. M111.233916

Misener SR, Walker VK, (2000) Extraordinarily high density of unrelated genes showing overlapping and intraintronic transcription units. Biochim Biophys Acta 1492: 269-270

Modarresi F, Faghihi MA, Lopez-Toledano MA, Fatemi RP, Magistri M, Brothers SP, Marcel P. van der Brug MP, Wahlestedt C (2012b) Natural Antisense Inhibition Results in Transcriptional De-Repression and Gene Upregulation. Nat Biotechnol 30: 453-459. http:// dx.doi.org/10.1038/nbt.2158

Modarresi F, Faghihi MA, Lopez-Toledano MA, Fatemi RP, Magistri M, Brothers SP, van der Brug MP, Wahlestedt C, (2012a) Inhibition of natural antisense transcripts in vivo results in gene-specific transcriptional upregulation. Nat Biotechnol 30: 453-459. http://dx.doi. org/10.1038/nbt.2158

Modarresi F, Faghihi MA, Patel NS, Sahagan BG, Wahlestedt C, Lopez-Toledano MA, (2011) Knockdown of BACE1-AS Nonprotein-Coding Transcript Modulates Beta-Amyloid-Related Hippocampal Neurogenesis. Int J Alzheimers Dis 2011: 929042. http://dx.doi. org $/ 10.4061 / 2011 / 929042$

Mol JN, van der Krol AR, van Tunen AJ, van Blokland R, de Lange P, Stuitje AR, (1990) Regulation of plant gene expression by antisense RNA. FEBS Lett 268: 427-430

Munroe SH, Lazar MA, (1991) Inhibition of c-erbA mRNA splicing by a naturally occurring antisense RNA. J Biol Chem 266: 22083-22086

Munroe SH, Morales CH, Duyck TH, Waters PD, (2015) Evolution of the Antisense Overlap between Genes for Thyroid Hormone Receptor and Rev-erbalpha and Characterization of an Exonic G-Rich Element That Regulates Splicing of TRalpha2 mRNA. PLoS One 10: e0137893. http://dx.doi.org/10.1371/journal.pone.0137893

Muramatsu M, Kinoshita K, Fagarasan S, Yamada S, Shinkai Y, Honjo $\mathrm{T},(2000)$ Class switch recombination and hypermutation require activation-induced cytidine deaminase (AID), a potential RNA editing enzyme. Cell 102: 553-563

Muro EM, Andrade-Navarro MA, (2010) Pseudogenes as an alternative source of natural antisense transcripts. BMC Evol Biol 10: 338. http://dx.doi.org/10.1186/1471-2148-10-338

Nigita G, Veneziano D, Ferro A, (2015) A-to-I RNA editing: current knowledge sources and computational approaches with special em- 
phasis on non-coding RNA molecules. Front Bioeng Biotechnol 3: 37. http://dx.doi.org/10.3389/fbioe.2015.00037

Oeder S, Mages J, Flicek P, Lang R, (2007) Uncovering information on expression of natural antisense transcripts in Affymetrix MOE430 datasets. BMC Genomics 8: 200. http://dx.doi.org/10.1186/14712164-8-200

Ohhata T, Matsumoto M, Leeb M, Shibata S, Sakai S, Kitagawa K, Niida H, Kitagawa M, Wutz A, (2015) Histone H3 lysine 36 trimethylation is established over the Xist promoter by antisense Tsix transcription and contributes to repressing Xist expression. Mol Cell Biol 35: 3909-3920. http://dx.doi.org/10.1128/MCB.00561-15

Okamura K, Robine N, Liu Y, Liu Q, Lai EC, (2011) R2D2 organizes small regulatory RNA pathways in Drosophila. Mol Cell Biol 31: 884-896. http://dx.doi.org/10.1128/MCB.01141-10

Osato N, Suzuki Y, Ikeo K, Gojobori T, (2007) Transcriptional interferences in cis natural antisense transcripts of humans and mice. Genetics 176: 1299-1306. http://dx.doi.org/10.1534/genetics.106.069484

Osato N, Yamada H, Satoh K, Ooka H, Yamamoto M, Suzuki K, Kawai J, Carninci P, Ohtomo Y, Murakami K, Matsubara K, Kikuchi S, Hayashizaki Y, (2003) Antisense transcripts with rice fulllength cDNAs. Genome Biol 5: R5. http://dx.doi.org/10.1186/gb2003-5-1-r5

Pandey RR, Mondal T, Mohammad F, Enroth S, Redrup L, Komorowski J, Nagano T, Mancini-Dinardo D, Kanduri C, (2008) Kcnq1ot1 antisense noncoding RNA mediates lineage-specific transcriptional silencing through chromatin-level regulation. Mol Cell 32: 232-246. http://dx.doi.org/10.1016/j.molcel.2008.08.022

Parenti R, Paratore S, Torrisi A, Cavallaro S, (2007) A natural antisense transcript against Rad18, specifically expressed in neurons and upregulated during beta-amyloid-induced apoptosis. Eur J Neurosci 26: 2444-2457. http://dx.doi.org/10.1111/j.1460-9568.2007.05864.x

Pasmant E, Sabbagh A, Vidaud M, Bieche I, (2011) ANRIL, a long, noncoding RNA, is an unexpected major hotspot in GWAS. FASEB J 25: 444-448. http://dx.doi.org/10.1096/fj.10-172452

Pefanis E, Wang J, Rothschild G, Lim J, Chao J, Rabadan R, Economides AN, Basu U, (2014) Noncoding RNA transcription targets AID to divergently transcribed loci in B cells. Nature 514: 389-393. http://dx.doi.org/10.1038/nature13580

Peters NT, Rohrbach JA, Zalewski BA, Byrkett CM, Vaughn JC, (2003) RNA editing and regulation of Drosophila $4 \mathrm{f}-\mathrm{rnp}$ expression by sas10 antisense readthrough mRNA transcripts. RNA 9: 698-710

Portal MM, Pavet V, Erb C, Gronemeyer H, (2015) Human cells contain natural double-stranded RNAs with potential regulatory functions. Nat Struct Mol Biol 22: 89-97. http://dx.doi.org/10.1038/ nsmb.2934

Quesada V, Ponce MR, Micol JL, (1999) OTC and AUL1, two convergent and overlapping genes in the nuclear genome of Arabidopsis thaliana. FEBS Lett 461: 101-106

Ramaswami G, Li JB, (2014) RADAR: a rigorously annotated database of A-to-I RNA editing. Nucleic Acids Res 42: D109-13. http://dx.doi. org/10.1093/nar/gkt996

Roberts TC, Morris KV, (2013) Not so pseudo anymore: pseudogenes as therapeutic targets. Pharmacogenomics 14: 2023-2034. http://dx.doi. org/10.2217/pgs.13.172

Sanger F, Air GM, Barrell BG, Brown NL, Coulson AR, Fiddes CA, Hutchison CA, Slocombe PM, Smith M, (1977) Nucleotide sequence of bacteriophage phi X174 DNA. Nature 265: 687-695

Scheele C, Petrovic N, Faghihi MA, Lassmann T, Fredriksson K, Rooyackers O, Wahlestedt C, Good L, Timmons JA, (2007) The human PINK1 locus is regulated in vivo by a non-coding natural antisense RNA during modulation of mitochondrial function. BMC Genomics 8: 74. http://dx.doi.org/10.1186/1471-2164-8-74

Shearwin KE, Callen BP, Egan JB, (2005) Transcriptional interference--a crash course. Trends Genet 21: 339-345. http://dx.doi. org/10.1016/j.tig.2005.04.009

Shendure J, Church GM, (2002) Computational discovery of sense-antisense transcription in the human and mouse genomes. Genome Biol 3: RESEARCH0044

Spencer CA, Gietz RD, Hodgetts RB, (1986) Overlapping transcription units in the dopa decarboxylase region of Drosophila. Nature 322: 279-281. http://dx.doi.org/10.1038/322279a0

Stazic D, Lindell D, Steglich C, (2011) Antisense RNA protects mRNA from RNase E degradation by RNA-RNA duplex formation during phage infection. Nucleic Acids Res 39: 4890-4899. http://dx.doi. org/10.1093/nar/gkr037

Steigele S, Nieselt K, (2005) Open reading frames provide a rich pool of potential natural antisense transcripts in fungal genomes. Nucleic Acids Res 33: 5034-5044. http://dx.doi.org/10.1093/nar/gki804

Stolc V, Samanta MP, Tongprasit W, Sethi H, Liang S, Nelson DC, Hegeman A, Nelson C, Rancour D, Bednarek S, Ulrich EL, Zhao Q, Wrobel RL, Newman CS, Fox BG, Phillips GN Jr, Markley JL, Sussman MR, (2005) Identification of transcribed sequences in Arabidopsis thaliana by using high-resolution genome tiling arrays. Proc Natl Acad Sci U S A 102: 4453-4458. http://dx.doi.org/10.1073/ pnas.0408203102
Szczesniak MW, Makalowska I, (2016) lncRNA-RNA Interactions across the Human Transcriptome. PLoS One 11: e0150353. http:// dx.doi.org/10.1371/journal.pone.0150353

Szczesniak MW, Rosikiewicz W, Makalowska I, (2016) CANTATAdb: A Collection of Plant Long Non-Coding RNAs. Plant Cell Physiol 57: e8. http://dx.doi.org/10.1093/pcp/pcv201

Szekely M (1977) PhiX174 sequenced. Nature 265: 685. http://dx.doi. org/10.1038/265685a0

Tam OH, Aravin AA, Stein P, Girard A, Murchison EP, Cheloufi S, Hodges E, Anger M, Sachidanandam R, Schultz RM, Hannon GJ, (2008) Pseudogene-derived small interfering RNAs regulate gene expression in mouse oocytes. Nature 453: 534-538. http://dx.doi. org/10.1038/nature06904

Tufarelli C, Stanley JA, Garrick D, Sharpe JA, Ayyub H, Wood WG, Higgs DR, (2003) Transcription of antisense RNA leading to gene silencing and methylation as a novel cause of human genetic disease. Nat Genet 34: 157-165. http://dx.doi.org/10.1038/ng1157

van Duin M, van Den Tol J, Hoeijmakers JH, Bootsma D, Rupp IP, Reynolds P, Prakash L, Prakash S, (1989) Conserved pattern of antisense overlapping transcription in the homologous human ERCC-1 and yeast RAD10 DNA repair gene regions. Mol Cell Biol 9: $1794-1798$

van Heesch S, van Iterson M, Jacobi J, Boymans S, Essers PB, de Bruijn E, Hao W, MacInnes AW, Cuppen E, Simonis M, (2014) Extensive localization of long noncoding RNAs to the cytosol and mono- and polyribosomal complexes. Genome Biol 15: R6. http:// dx.doi.org/10.1186/gb-2014-15-1-r6

Vanhee-Brossollet C, Vaquero C, (1998) Do natural antisense transcripts make sense in eukaryotes? Gene 211: 1-9

Veeramachaneni V, Makalowski W, Galdzicki M, Sood R, Makalowska I, (2004) Mammalian overlapping genes: the comparative perspective. Genome Res 14: 280-286. http://dx.doi.org/10.1101/gr.1590904

Vollmers C, Schmitz RJ, Nathanson J, Yeo G, Ecker JR, Panda S, (2012) Circadian oscillations of protein-coding and regulatory RNAs in a highly dynamic mammalian liver epigenome. Cell Metab 16: 833-845. http://dx.doi.org/10.1016/j.cmet.2012.11.004

Wang GQ, Wang Y, Xiong Y, Chen XC, Ma ML, Cai R, Gao Y, Sun YM, Yang GS, Pang WJ, (2016) Sirt1 AS lncRNA interacts with its mRNA to inhibit muscle formation by attenuating function of miR34a. Sci Rep 6: 21865. http://dx.doi.org/10.1038/srep21865

Wang H, Chua NH, Wang XJ, (2006) Prediction of trans-antisense transcripts in Arabidopsis thaliana. Genome Biol 7: R92. http:// dx.doi.org/10.1186/gb-2006-7-10-r92

Wang Q, Carmichael GG, (2004) Effects of length and location on the cellular response to double-stranded RNA. Microbiol Mol Biol Rev 68: 432-452, table of contents. http://dx.doi.org/10.1128/ MMBR.68.3.432-452.2004

Wang XJ, Gaasterland T, Chua NH, (2005) Genome-wide prediction and identification of cis-natural antisense transcripts in Arabidopsis thaliana. Genome Biol 6: R30. http://dx.doi.org/10.1186/gb-2005-64-r30

Watanabe T, Totoki Y, Toyoda A, Kaneda M, Kuramochi-Miyagawa S, Obata Y, Chiba H, Kohara Y, Kono T, Nakano T, Surani MA, Sakaki Y, Sasaki H, (2008) Endogenous siRNAs from naturally formed dsRNAs regulate transcripts in mouse oocytes. Nature 453: 539-543. http://dx.doi.org/10.1038/nature06908

Werner A, Cockell S, Falconer J, Carlile M, Alnumeir S, Robinson J, (2014) Contribution of natural antisense transcription to an endogenous siRNA signature in human cells. BMC Genomics 15: 19. http:// dx.doi.org/10.1186/1471-2164-15-19

Wery M, Descrimes M, Vogt N, Dallongeville AS, Gautheret D, Morillon A, (2016) Nonsense-mediated decay restricts LncRNA levels in yeast unless blocked by double-stranded RNA structure. Mol Cell 61: 379-392. http://dx.doi.org/10.1016/j.molcel.2015.12.020

Wight M, Werner A, (2013) The functions of natural antisense transcripts. Essays Biochem 54: 91-101. http://dx.doi.org/10.1042/ bse 0540091

Williams T, Fried M, (1986) A mouse locus at which transcription from both DNA strands produces mRNAs complementary at their 3' ends. Nature 322: 275-279. http://dx.doi.org/10.1038/322275a0

Xue Z, Ye Q, Anson SR, Yang J, Xiao G, Kowbel D, Glass NL, Crosthwaite SK, Liu Y, (2014) Transcriptional interference by antisense RNA is required for circadian clock function. Nature 514: 650-653. http://dx.doi.org/10.1038/nature13671

Yamada K, Lim J, Dale JM, Chen H, Shinn P, Palm CJ, Southwick AM, Wu HC, Kim C, Nguyen M, Pham P, Cheuk R, Karlin-Newmann G, Liu SX, Lam B, Sakano H, Wu T, Yu G, Miranda M, Quach HL, Tripp M, Chang CH, Lee JM, Toriumi M, Chan MM, Tang CC, Onodera CS, Deng JM, Akiyama K, Ansari Y, Arakawa T, Banh J, Banno F, Bowser L, Brooks S, Carninci P, Chao Q, Choy N, Enju A, Goldsmith AD, Gurjal M, Hansen NF, Hayashizaki Y, Johnson-Hopson C, Hsuan VW, Iida K, Karnes M, Khan S, Koesema E, Ishida J, Jiang PX, Jones T, Kawai J, Kamiya A, Meyers C, Nakajima M, Narusaka M, Seki M, Sakurai T, Satou M, Tamse R, Vaysberg M, Wallender EK, Wong C, Yamamura Y, Yuan S, Shinozaki K, Davis RW, Theologis A, Ecker JR, (2003) Empirical 
analysis of transcriptional activity in the Arabidopsis genome. Science 302: 842-846. http://dx.doi.org/10.1126/science.1088305

Yelin R, Dahary D, Sorek R, Levanon EY, Goldstein O, Shoshan A, Diber A, Biton S, Tamir Y, Khosravi R, Nemzer S, Pinner E, Walach S, Bernstein J, Savitsky K, Rotman G, (2003) Widespread occurrence of antisense transcription in the human genome. Nat Biotechnol 21: 379-386. http://dx.doi.org/10.1038/nbt808

Yu D, Meng Y, Zuo Z, Xue J, Wang H, (2016) NATpipe: an integrative pipeline for systematical discovery of natural antisense transcripts (NATs) and phase-distributed nat-siRNAs from de novo assembled transcriptomes. Sci Rep 6: 21666. http://dx.doi. org/10.1038/srep21666

Yu W, Gius D, Onyango P, Muldoon-Jacobs K, Karp J, Feinberg AP, Cui H, (2008) Epigenetic silencing of tumour suppressor gene p15 by its antisense RNA. Nature 451: 202-206. http://dx.doi. org/10.1038/nature06468
Zhang L, Yang CS, Varelas X, Monti S, (2016) Altered RNA editing in 3' UTR perturbs microRNA-mediated regulation of oncogenes and tumor-suppressors. Sci Rep 6: 23226. http://dx.doi.org/10.1038/ srep23226

Zhang X, Xia J, Lii YE, Barrera-Figueroa BE, Zhou X, Gao S, Lu L, Niu D, Chen Z, Leung C, Wong T, Zhang H, Guo J, Li Y, Liu R, Liang W, Zhu JK, Zhang W, Jin H, (2012) Genome-wide analysis of plant nat-siRNAs reveals insights into their distribution, biogenesis and function. Genome Biol 13: R20. http://dx.doi.org/10.1186/ gb-2012-13-3-r20

Zhang Y, Liu XS, Liu QR, Wei L, (2006) Genome-wide in silico identification and analysis of cis natural antisense transcripts (cis-NATs) in ten species. Nucleic Acids Res 34: 3465-3475. http://dx.doi. org/10.1093/nar/gkl473

Zhou C, Blumberg B, (2003) Overlapping gene structure of human VLCAD and DLG4. Gene 305: 161-166 